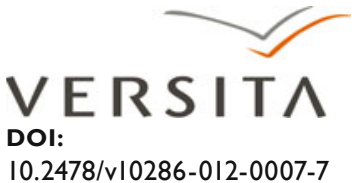

Management

2012

Vol.16, No. 1

ISSN 1429-9321

\begin{abstract}
ARKADIUSZ ŚWIADEK JOANNA WIŚNIEWSKA
\end{abstract}

\title{
Endogenous or exogenous innovative development in companies on regional level? Case study - lubuskie voivoidship
}

Professor Arkadiusz Świadek University in Zielona Góra

Joanna Wiśniewska, Ph.D. University of Szczecin

\section{Introduction}

While studying the literature on modern economic growth theories, we usually come across two groups of theories: exogenous and endogenous. The criterion which assigns a theory to a particular group depends on the causes of the growth. If the growth is caused by factors which are coming from the inside of a given object (region, country), then we are dealing with endogenous growth. In turn, if the economic growth is caused by factors coming from the outside of the studied object, then we are dealing with exogenous growth.

The first attempts of creating theories ofendogenousgrowthdateback tothebeginning of the 1960s, when the works of N. Kalder, J. K. Arrow and N. Kalder with J. A. Miralessa (Malaga 2009) were published.

Rapid growth of interest in endogenous growth theories fell however on the 1980s and 1990s, when the main growth models by P. Romer (1986) and R. E. Lucas (1988) appeared. Those theories are based on the Assumption, that production volume is a function, dependant of the level and technological capital. An interesting fact is, that they treat technological 


$$
\begin{aligned}
& \text { Management } \\
& 2012 \\
& \text { Vol.16, No. } 1
\end{aligned}
$$

level not as an exogenous variable, like in classic models, but as an endogenous variable. It is the result of the fact that, the level depends of the size of expenses, made by companies and authorities in a given region. Apart of that, P. Romer points to the fact that, a stronger barrier for the development of a region or country is the gap in technological knowledge rather than capital barrier and investment opportunities (Romer 1990). Romers' Model also points out that, regions can differ in terms of wealth and level of economic development. Rich regions are characterized by better access to science and research facilities both in quantitative and qualitative terms. In such regions more people can be working in the science and research industries. Weaker regions, however will not reach welfare growth, until their technological level will improve. Such situation contributes to the progressive divergence of regions in terms of economic growth.

A chance of leaving this vicious circle is to trade with more developed regions and inflow of both material capital (financial and material), but mainly human. It is immensely difficult, since it may be easy to attract material capital to investments in a backward region (for instance thanks to the tax advantages), human capital is characterized by an opposite tendency, people with better education tend to leave regions, where the standard of living is lower than in better developed regions. This contributes to the fact that, rich regions become stronger, have bigger accumulation of human capital and poor regions become even weaker.

L.A. Rivera-Batiz and D. Xie express in similar style. According to their thesis's free trade in a model of endogenous growth considering high-end technology, related to the development of research-development sector, leads to the convergence of regional income. One has to remember that convergence depends of the mobility of the capital and the process of innovation diffusion, which is not always possible in case on weaker regions (Rivera-Batiz, Xie 1993).

As it was mentioned earlier, endogenous theories are based on the assumption, the technological level was treated as a endogenous variable, that is dependant from the factor localized inside the studied object. It is an obvious thesis In case of well developed regions. However, most of Polish voivodeships cannot be included to them. Therefore, the question arises, is the development in Polish reality based on the influence of internal or external conditions, and therefore can it be treated as an endogenous or exogenous?

Dynamism and consistency of technological development have been described in theoretical currents, known as the evolutionary and neo-schumpeterian school. In those concepts he innovation process on the level of a company is considered to be a set of activities that are mutually connected with each

87 
other and bound by mutual feedback. Innovation is therefore the result of an interactive process of studying, which often employs a few actors from the inside and outside of a company (Lundvall 1992).

Innovation systems became the subject of theoretical-empirical studies in the past 20-25 years. This approach focuses on the determinants of development and diffusion of product and process innovations. It's being are the relations occurring between internal and external region participants (Sternberg 2000). Conclusions from the conduced research show that, production subjects achieve better success when they are the elements of intense network integration.

The outlined conceptual framework has triggered the taking up of the problem of confronting endogenous and exogenous factors on the innovativeness of regional industrial system. At present, the theory of endogenous growth is becoming more and more popular in the world of science, especially in well developed countries. In this context the basic hypothesis of the conduced research was the statement that the development of lubuskie region as well as other underdeveloped regions of Poland is mostly dependant on the measure of endogenous factors.

The main goal of the study was an attempt to show, based on lubuskie voivodeships, the opportunities and legitimacy of application of the theory of endogenous growth in underdeveloped regions.

Present analyses have been conducted based on an questionnaire given to a group of 545 industrial businesses from lubuskie region. The basic way of data collection was a procedure that combined an initial phone conversation with sending a questionnaire by mail - traditional or e-mail.

\section{Methodical conditions of conducted research - probit modelling}

Methodical part of analyses was based on the Theory of Probability. The seventeen variables included (OECD 2005):

a) the incidence of expenditure on innovative activity in relation to their structure (research and development, investing in new machinery and technical equipment, investing in buildings and grounds, new software),

$$
Y_{1 i}=\left\{\begin{array}{c}
1, \mathrm{f} \text { the expenditure was present } \\
0 \mathrm{f} \text { the expenditure was not present }
\end{array}\right.
$$


b) implementation of new products and processes, also including detailed solutions in this respect (new products, new technological processes),

$$
Y_{2 i}=\left\{\begin{array}{c}
1 \mathrm{f} \text { a new solution was introduced } \\
0 \mathrm{f} \text { a new solution was not introduced }
\end{array}\right.
$$

c) innovative cooperation in subject approach (with suppliers, competitors, customers, universities, R\&D centres, foreign research institutes).

$$
Y_{3 i}=\left\{\begin{array}{l}
1, \mathrm{f} \text { there was a cooperation } \\
0 \mathrm{f} \text { there was } \mathrm{n} \text { cooperation }
\end{array}\right.
$$

Independent variables that were used in the research were: the character of the company's ownership (state, foreign, mixed), range of sales (local, regional, national, international), distance to the closest competitor (local, regional, country, foreign), the character of the relations held with the competitor (only essential, close cooperation), the distance to the main supplier (local, regional, country, foreign), character of the relations held with the supplier (essential, close cooperation), distance from the main customer (local, regional, national, foreign), character of the relations held with the customer (essential, close cooperation), which were identified by company owners based on the carried out survey.

The adopted independent variables are a set of reference planes that present the innovative activity of companies adopted on the basis of methodologies used for OECD countries (OECD 2005)

In case when, the dependant variable achieves dichotomous values the commonly adopted in case of quantitative phenomena, multiple regression cannot be adopted. An alternative solution for this problem is the adoption of Probit regression. Its advantage is the fact that, the analysis and interpretation of results is similar to the classic regression method. Therefore the ways of selection of variables and hypothesis testing have a similar scheme. Although there are also differences, like for example more complex and time consuming calculations or the calculation of value and preparation of charts presenting the reminder often do not bring anything important to the model (Stanisz 2007).

In case of a model, where the dependant variable achieves the value of 0 or 1 , the value of the expected variable can be interpreted as the conditioned probability of realization of a given occurrence at fixed values of independent variables.

89 
The application of Probit modelling allowed the evaluation of the occurring chance of different innovative behaviours depending on the adopted boundary conditions.

Estimation of parameters in methods with dichotomous variable is done by a method of the biggest credibility. According to its principles, one needs to find a vector of parameters, which guarantees the biggest likelihood of obtaining values observed in the sample (Welfe 1998). Briefly speaking, the use of the biggest credibility method requires formulation of a credibility function and finding its extreme, which can be done in an analytical or numerical manner. Despite a quite complicated form biggest credibility method has become popular, because it can be applied in case of a broad array of models including those with variable parameters and those with a complex structure of delays, heteroxedastic as well as non-linear. The properties of MWN also in small samples are in many cases better than the other, competitive estimators (Welfe 1998).

The maximization of the credibility function for a Probit model is done by using techniques used for non-linear estimation. For Probit analysis simple computer applications are available (Maddala 2006).

Statistical verification of the models was carried out based on Wald's Chiquadrant statistic, while the verification of the significance of the parameters by $t$-student test using asymptotic standard evaluation mistakes. All calculations have been carried out with the Statistica software. Due to the aesthetics of presenting the results of the study, the authors decided to present only models that fulfil the criteria regarding the significance of models and parameters, therefore resigning from a complex form of presentation like the statistics of evaluation of parameter's significance and the model as a whole, however taking into consideration the calculated standard mistakes and probabilities of occurrence of particular phenomena. It was also justified by the fact, that the structural form of the model is sufficient for the analysis of the analyzed phenomena.

Due to the difficulties in interpretation connected with Probit modelling the decision has been made to create one factor models.

Taking into consideration the fact that all variables adopted to the study, both dependant and independent have a binary character (they reach values 0 or 1) interpretation of results will be carried out based on the structural form of the model. A plus sign by a parameter means that the probability of occurrence of an innovative action is higher in a separated category of companies in relation to the rest of the community. Probit modelling is an accurate research tool in case of large, by static samples in which the dependant variable has a qualitative form.

Endogenous or exogenous innovative development in companies on regional level? Case study - lubuskie voivoidship 


\section{Characteristic of research sample}

As it was mentioned in the introduction, the study has been carried out based on a sample of 545 industrial companies from lubuskie voivodeship. The structure of the studied companies form the size and technology point of view is presented in the table below.

Table 1. Structure of industrial companies in lubuskie voivodeship from the perspective of the size and the used technology of the company in 2008-10 (in percent)

\begin{tabular}{c|l|c|c|c}
\hline No & Size of companies & Lubuskie region & Technology advance & Lubuskie region \\
\hline 1 & Micro & 27,2 & High & 3,3 \\
\hline 2 & Small & 39,4 & Medium-high & 10,1 \\
\hline 3 & Medium & 23,7 & Medium-low & 27,3 \\
\hline 4 & Large & 9,7 & Low & $5 \ldots \ldots \ldots \ldots \ldots \ldots \ldots$ \\
\hline
\end{tabular}

Source: Own studies based on performed research

Furthermore from the perspective of the quantitative sample the results are similar or exceed those carried out by the Central Office of Statistics on the discussed issue.

\section{Selected determinants of innovative activity in lubuskie voivodeship}

Ownership character in lubuskie region is one of the main determinants explaining the actual condition of industry innovativeness. State companies show little interest in modernization of production and offering new products. It is a serious problem of the system, which is probably the result of the isolation of those companies in the region, which in turn is the consequence of lack of contacts with companies responsible for transferring technology to the voivodeship.

91 
Table 2. Probit form for the independent variable "character of company's ownership", in models describing the innovation of industry in lubuskie voivodeship

\begin{tabular}{|c|c|c|c|}
\hline \multirow{2}{*}{ Innovative feature } & \multicolumn{3}{|c|}{ Character of company's ownership } \\
\hline & Domestic & Foreign & Mixed \\
\hline R\&D expenditure & $-, 71 x+0,08$ & $+, 87 x-0,58$ & \\
\hline Investment in new fixed assets & $-, 44 x+1,04$ & & $+, 67 x+0,65$ \\
\hline \multicolumn{4}{|l|}{ a) building and grounds } \\
\hline b) technical equipment and machinery & $-, 73 x+1,01$ & $+, 53 x+0,37$ & $+, 94 x+0,37$ \\
\hline Software solution & $-, 69 x+0,79$ & $+, 73 x+0,16$ & $+, 41 x+0,22$ \\
\hline Launching new products & $-, 62 x+1,01$ & $+, 59 x+0,45$ & $+, 55 x+0,48$ \\
\hline $\begin{array}{l}\text { Implementation of new technology process } \\
\text { (including): }\end{array}$ & $-, 46 x+1,04$ & & $+, 96 x+0,62$ \\
\hline a) new production methods & $-, 29 x+0,23$ & & \\
\hline b) none production systems & $-, 48 x-0,05$ & & $+, 63 x-0,47$ \\
\hline c) support systems & $-, 30 x-0,51$ & & $+, 42 x-0,78$ \\
\hline Cooperation with foreign science units & $-, 74 x-1,70$ & & $+, 67 x-2,25$ \\
\hline Cooperation with customers & $-, 38 x-0,41$ & & $+, 48 x-0,74$ \\
\hline Overall innovation cooperation & $-, 26 x+0,18$ & & $+, 37 x-0,06$ \\
\hline
\end{tabular}

Opposed to national units are usually companies with a mixed structure of ownership, but also typically foreign countries. It means that the actual condition necessary for running an innovative business activity is having in one's stricter foreign capital. In other words technology transfer into a region takes place mainly thanks to companies domiciled abroad in case when national companies become weaker.

Differences between international companies and those with a mixed structure mainly concern innovative cooperation. The latter are excessively cooperation in the innovation area especially with international research and development units and the recipients of the produced goods.

It is also worth noting that innovative activity is shifting from companies with only foreign ownership to those with a mixed ownership structure in comparison to the research carried out five years ago. 


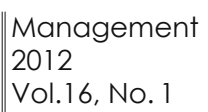

Table 3. Probit form for the independent variable "range of sales", in models describing the innovation of industry in lubuskie voivodeship

\begin{tabular}{|c|c|c|c|c|}
\hline \multirow{2}{*}{ Innovative feature } & \multicolumn{4}{|c|}{ Range of sales } \\
\hline & local & regional & country & international \\
\hline R\&D expenditure & $-, 71 x-0,31$ & & & $+, 53 x-0,65$ \\
\hline Investment in new fixed assets & & & & $+, 36 x+0,58$ \\
\hline \multicolumn{5}{|l|}{ a) building and grounds } \\
\hline b) technical equipment and machinery & & & & $+, 49 x+0,27$ \\
\hline Software solution & $-, 58 x+0,38$ & $-, 31 x+0,31$ & $+, 22 x+0,16$ & $+, 70 x+0,01$ \\
\hline Launching new products & & & & $+, 48 x+0,36$ \\
\hline \multicolumn{5}{|l|}{$\begin{array}{l}\text { Implementation of new technology process } \\
\text { (including): }\end{array}$} \\
\hline a) new production methods & & & & $+, 36 x-0,12$ \\
\hline b) none production systems & & & & $+, 38 x-0,55$ \\
\hline c) support systems & $-, 48 x-0,65$ & & & $+, 29 \times-0,85$ \\
\hline Cooperation with universities & & & & $+, 43 x-2,04$ \\
\hline Cooperation with foreign science units & & & & $+, 99 x-2,75$ \\
\hline Cooperation with customers & & & & $+, 45 x-0,87$ \\
\hline Overall innovation cooperation & & & & $+, 24 x-0,11$ \\
\hline \multicolumn{5}{|l|}{$\triangle$} \\
\hline
\end{tabular}

Offering the produced goods on local and regional markets do not stimulate introduction of new solutions. A weak industrial system cannot draw information on new technologies not only from companies operating in the same region but also the national environment is not sufficient. It proves the weak connections of companies with other companies located in the region.

Strongly growing probability of implementation of innovation can be observed in case of companies offering their goods on foreign markets. It should be remembered that it concerns mostly medium and large companies as well as foreign and with mixed ownership structure. At the same time it is the most often appearing and at the same time strong element shaping not only the financing area and implementation of new solutions, but also mainly cooperation with other companies. International market therefore 


$$
\begin{array}{r}
\text { Management } \\
2012 \\
\text { Vol.16, No. } 1
\end{array}
$$

stimulates the flow of technology in case when the internal limits the process.

Table 4. Probit form for the independent variable "distance from competitor", in models describing the innovation of industry in lubuskie voivodeship

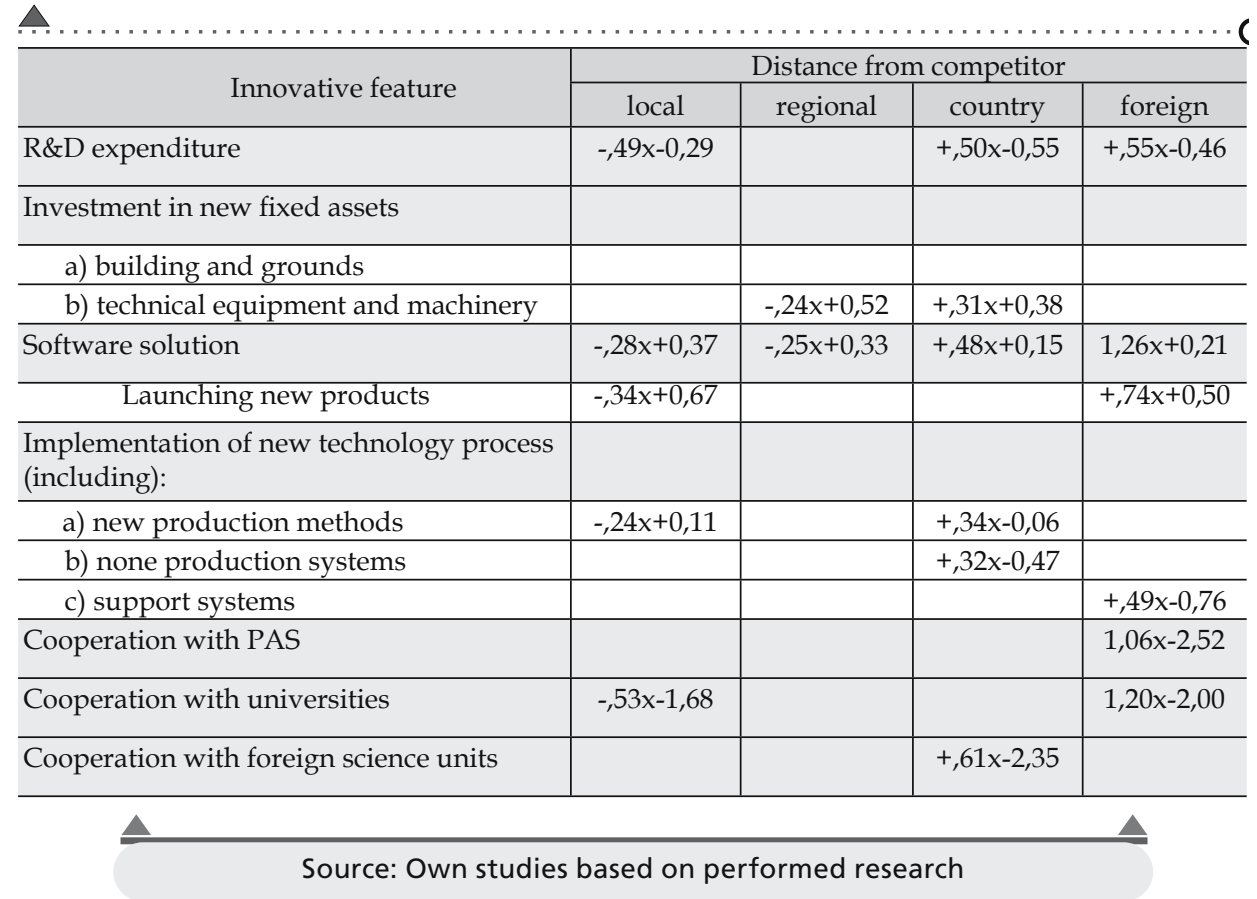

In case of relations of the studied companies with competitors one can see the two initial conclusions. The distance from the competitor has often a similar influence on shaping innovative activity as in case of customers and suppliers. The more distantly located the competitor is - not local and regional, the higher the innovative activity of the industry in the lubuskie voivodeship is. Maintaining relations with the competitor is rarely and ambiguously strengthening the imperative of heading to new solutions. The subject literature points out that positive relation with competing companies should intensify (concentration) innovative activities along proximal nearing; therefore, those processes should mutually determine themselves, which cannot be observed in this case. 


$$
\begin{aligned}
& \text { Management } \\
& 2012 \\
& \text { Vol.16, No. } 1
\end{aligned}
$$

Table 5. Probit form for the independent variable "relations with competitor", in models describing the innovation of industry in lubuskie voivodeship

\begin{tabular}{l|c|c}
\hline \multicolumn{1}{c}{ Innovative feature } & \multicolumn{2}{c}{ Relations with competitor } \\
\cline { 2 - 3 } Investment in new fixed assets & none contacts & close \\
\hline a) building and grounds & & \\
\hline b) technical equipment and machinery & & $-, 37 \mathrm{x}+0,50$ \\
\hline Software solution & & $+, 49 \mathrm{x}+0,19$ \\
\hline$\quad$ Launching new products & & $+, 41 \mathrm{x}+0,47$ \\
\hline Cooperation with competitors & $-, 24 \mathrm{x}-0,57$ & \\
\hline Cooperation with customers & & \\
\hline \multicolumn{2}{c}{$\Delta \quad$ Source: Own studies based on performed research }
\end{tabular}

A small distance to the competitor (local or regional) does not contribute to accelerating progress, but just the opposite. An alternative (contrary) situation takes place in case of supra-regional contacts. It is probably the result of the weakness of intra-regional industrial system characterized by a high knowledge deficiency and resistance in its flow.

Creating innovation through rivalry, often occurring between neighbouring companies, according to the literature it should be beneficial, but only in a short period of time (temporary benefits), because according to classic economy companies dedicate material and financial goods necessary for confrontation conditions. Therefore they limit their research and development potential, with its immanent feature - long term. Loss is also incurred by the region, because driving away of companies offering products on local and international markets takes place. From the regional point of view, the balance does not change fundamentally in relation to the exit point, the stronger company remains, however at the expense of those, who have lost their market.

In case of suppliers spatial interactions and those regarding interpersonal relationships are presented in a similar way as in case of competitors. The distance from the supplier is also important for the innovativeness of the region. More often however than for the competitors the character of mutual relationship is important. As previously the location of the supplier in close proximity is rather unstimulating for innovative activity. 


$$
\begin{array}{r}
\text { Management } \\
2012 \\
\text { Vol.16, No. } 1
\end{array}
$$

Table 6. Probit form for the independent variable "distance from supplier"

\begin{tabular}{|c|c|c|c|c|}
\hline \multirow{2}{*}{ Innovative feature } & \multicolumn{2}{|c|}{ Distance from supplier } & \multicolumn{2}{|c|}{ Relations with suppliers } \\
\hline & local & international & necessary & close \\
\hline R\&D expenditure & & $+, 49 x-0,49$ & $-, 36 x-0,36$ & \\
\hline Investment in new fixed assets & & & $-, 30 x+0,77$ & \\
\hline \multicolumn{5}{|l|}{ a) building and grounds } \\
\hline b) technical equipment and machinery & & $+, 41 x+0,40$ & & $+, 24 x+0,28$ \\
\hline Software solution & $-, 30 x+0,32$ & $+, 97 x-0,16$ & $-, 34 x+0,33$ & $+, 29 x+0,06$ \\
\hline Launching new products & & & $-, 45 x+0,63$ & $+, 32 x+0,32$ \\
\hline $\begin{array}{l}\text { Implementation of new technology } \\
\text { process (including): }\end{array}$ & & & $-, 41 x+0,79$ & $+, 27 x+0,52$ \\
\hline \multicolumn{5}{|l|}{ a) new production methods } \\
\hline b) none production systems & & & $-, 34 x-0,33$ & $+, 25 x-0,56$ \\
\hline c) support systems & $-, 34 x-0,67$ & $+, 61 x-0,82$ & $-, 33 x-0,67$ & $+, 33 x-0,96$ \\
\hline Cooperation with competitors & & & $-, 65 x-1,30$ & \\
\hline Cooperation with universities & & $+, 66 x-1,96$ & & \\
\hline Cooperation with customers & & $+, 46 x-0,75$ & & \\
\hline
\end{tabular}
and "relations with suppliers", in models describing the innovation of industry in lubuskie voivodeship

However, especially unfavourable seem to be the conditions of limited contacts with suppliers. Companies maintaining only essential relations with this group present a very low tendency to carry out innovative activities. For a change close cooperation with suppliers remains in strict relationship with financing and implementation of new technologies. It is worth noting that frequency of occurrence of negative influence is higher that the occurrence of positive, which means that one should not only support the construction of proper relations with customers but eliminating obstacles in cooperation with them. 


$$
\begin{aligned}
& \text { Management } \\
& 2012 \\
& \text { Vol.16, No. } 1
\end{aligned}
$$

Table 7. Probit form for the independent variable "distance from customer" and "relations with customers", in models describing the innovation of industry in lubuskie voivodeship

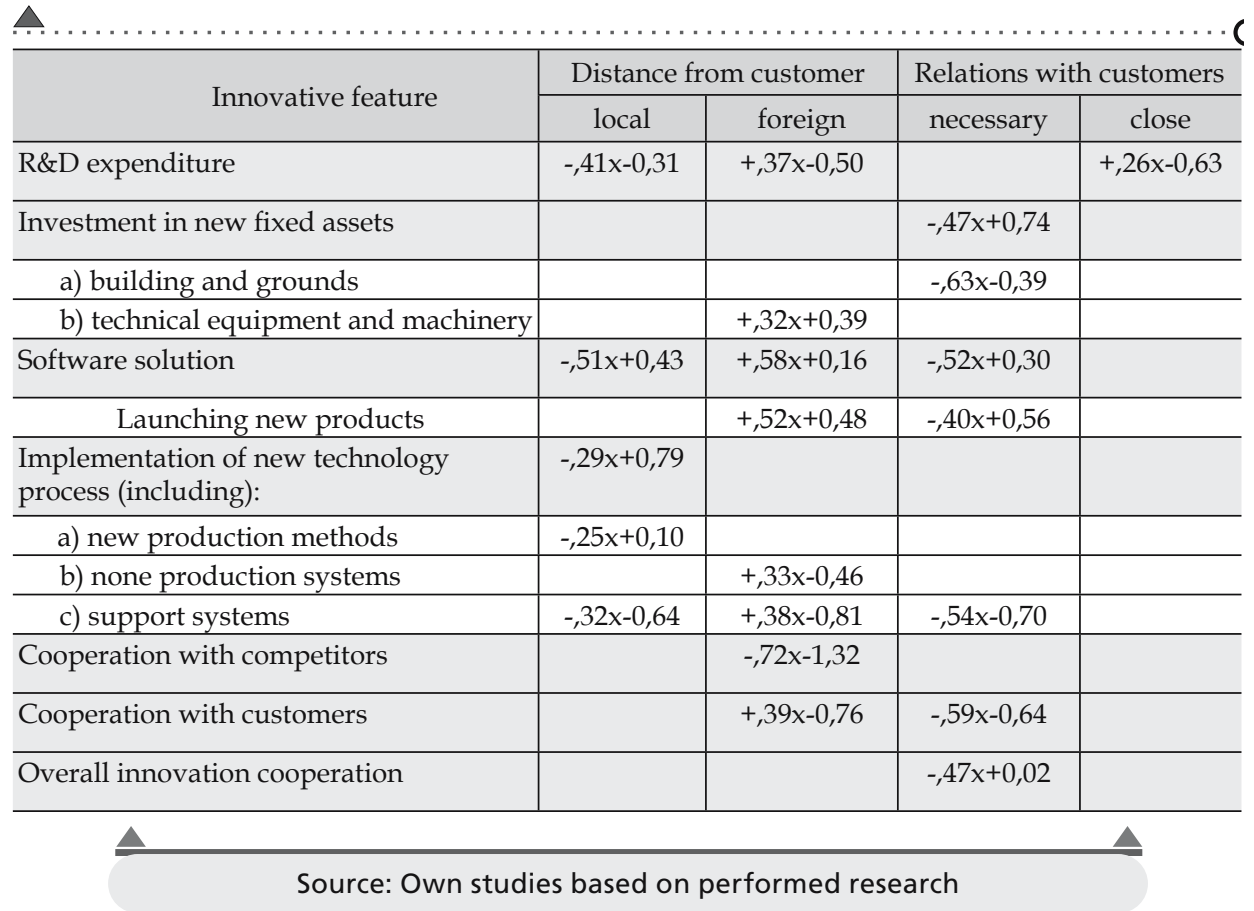

Spatial-relational connections with the customers in lubuskie region are similar to those that were observed in case of competitors and suppliers. Local contacts are unfavourable for companies. Different in case of relations held on large distances. Therefore locally there is no cooperation due to direct and repeatable contacts. Specificity of economically weak region does not stimulate carrying out of internal innovative processes in case, when companies with international contacts, due to quantitative-qualitative requirements and the knowledge-flow system, show interests in its conduction.

The character of connections with customers is characterized by a large heterogeneity, however multiple static models significantly suggest the imperative of not maintaining trace contacts with them. 


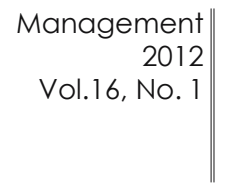

\section{Conclusions}

According to the theory of endogenous economical growth, factors favouring growth should be localized inside the studied object, in our case voivodeship. However, while analysing the data in the analytical part of this article it becomes clear that many factors favouring the innovative growth of industrial companies from the discussed voivodeship is located outside of them.

Taking into account the distance of competitors for innovative activity of industrial companies in the studied voivodeship a dependency becomes visible telling that companies become more innovative if their competitors are located in national or international scale. It is worth mentioning that innovative activity of industrial companies in the region is positively affected by the cooperation with competitors.

Analogically, having suppliers and customers, located abroad can positively influence innovative activity of industrial companies in the analysed voivodeship. Positive influence on innovative activity of companies is also strengthened by having close contacts with them. Remaining in neutral relations or even goodneighbour relations is insufficient for the improvement of innovative activity of companies.

Due to the low level of economic development many regions in Poland, including the studied example, cannot develop economically at a similar pace as the regions in developed countries. It causes economic divergence between weaker regions in Poland and well developed regions of Europe and the World. Due to the economic weakness of the regions internal factors stimulating economic growth are insufficient. Therefore, so important for the development, among others, of the studied voivodeship, are constant external impulses, which mean that the endogenous growth theory in weak regions in Poland has no right to exist. Without external impulses there can be no convergence. Therefore the economic development of most of Polish regions should be based on exogenous theory of economic growth.

\section{Summary}

Endogenous or exogenous innovative development in companies on regional level? Case study - lubuskie voivoidship

At the moment endogenous grow th theory has becomeincreasingly popular in the world of science, particularly in developed countries. This article aims to show, for lubuskie case, the needs and sense of applying this theory in the Polish regions. Due 


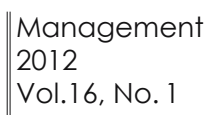

to the low level of economic development of many Polish regions, including Lubuskie, they are unable to growth in a comparable rate as regions in developed countries. This explains the economic divergence between polish regions and the highly developed regions of Europe and the World. Stimulating economic growth are insufficient in such cases, because of the weakness of the internal factors in regions. Therefore it is important to strengthen an external impulses to keep internal development. It means that the endogenous growth theory is no reason to exist, in conditions of poor Polish regions. Without external inputs there can't be convergences processes. Therefore, the economic development of the of Polish regions should be based on the exogenous growth theory.

\section{Streszczenie}

Endogeniczny czy egzogeniczny rozwój innowacji w przedsiębiorstwach na poziomie regionalnym? Studium przypadku - województwo lubuskie

W chwili obecnej teoria wzrostu endogenicznego staje się coraz bardziej popularna w świecie nauki, zwłaszcza w krajach rozwiniętych. Ten artykuł ma na celu ukazać, w oparciu o przypadek regionu lubuskiego, potrzebę i sens aplikacji tej teorii w polskich regionach. Ze względu na niski poziom rozwoju gospodarczego wielu regionów Polski, w tym lubuskiego, nie są one $\mathrm{w}$ stanie osiągnać wzrostu gospodarczego podobnego jak regiony w krajach rozwiniętych. To wyjaśnia różnice gospodarcze pomiędzy regionami Polski i wysokorozwiniętymi regionami Europy i świata. Stymulowanie wzrostu gospodarczego w takich przy padkachjest niewystarczające, ze względu na słabość w regionach czynników wewnętrznych. Dlatego w celu akceleracji rozwoju wewnętrznego istotne jest wzmocnienie go impulsami zewnętrznymi. Oznacza to, że teoria wzrostu endogenicznego nie ma racji bytu $w$ warunkach słabo rozwiniętych regionów Polski. Bez czynników zewnętrznych, nie może będą możliwe procesy konwergencji. Dlatego rozwój gospodarczy polskich regionów powinien być oparty na egzogennej teorii wzrostu gospodarczego. 


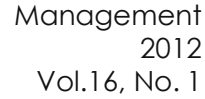

\section{References}

1. Lundvall D. A. (1992), Introduction. in: B.-A. Lundvall (ed.), National Systems of Innovation: Towards of Innovation and Interactive Learning, Pinter, London.

2. Maddala G.S. (2006), Ekonometria, Wyd. Nauk. PWN, Warszawa.

3. Malaga K. (2009), O niektórych dylematach teorii wzrostu gospodarczego i ekonomii, ZKP TE, Warszawa.

4. OECD and Eurostat (2005), Podręcznik Oslo. Zasady gromadzenia $i$ interpretacji danych dotyczacych innowacji. Third Edition.

5. Rivera-Batiz L. A., Xie D. (1993), Integration among unequals, "Regional Science and Urban Economics", No 23.

6. Romer P. (1990), Endogenous technological change, "Journal of Political Economy", vol. 98, no. 5, part II.

7. Stanisz A. (2007), Przystępny kurs statystki, Tom 2, Statsoft. Kraków.

8. Sternberg R. (2000), Innovation Networks and Regional Development Evidence from the European Regional Innovation Survey (ERIS), "European Planning Studies", Vol. 8, No 4.

9. Welfe A. (1998), Ekonometria, PWE, Warszawa. 